\title{
Rise of the Taliban and the US Intervention in Afghanistan
}

\author{
Shabnum Akhtar* \\ Ph.D Scholar of the Department of Political Science, Jamia Millia Islamia, New Delhi-110025.
}

\begin{abstract}
The people of Afghanistan have experienced long period of political instability. For the last three decades, the Afghan soil has experienced every form of conflict-international intervention, proxy war, civil war, and war on terrorism. The Paper will deal systematically with the Afghanistan's state of constant warfare right from Soviets left from Afghanistan, leaving their marks on the country and its population. The main focus of this paper is to analyze the situation of the Afghan society under and after the Taliban rule. The work will also highlight the socio-political circumstances that led to the emergence of the Taliban in Afghanistan. The paper will identify major US-policy-making errors with respect to state-building, military activities, and diplomacy after its intervention in Afghanistan. After the Taliban's 'defeat' in 2001, their resurgence was invited by the failure of state of justice and security institutions. Presently, Afghanistan is facing a triple threat of antigovernment insurgence, increased opium production, and growing popular discontent over corruption and government failures in Afghanistan.
\end{abstract}

Key Words: Afghan Society, Taliban, USA, Bonn Agreement, Afghan government, Northern Alliance.

\section{Introduction}

One would not be wrong to state that Afghanistan has the longest turbulent history in the world. After the communist coup in 1978, and the Soviet occupation at the end of 1979, it suffered a quarter-century conflict. Afghanistan became the battleground for the super power rivalry, with millions dead and disabled, and equally large number rendered homeless. Afghanistan has lost at least two generations of its people to war and dislocation. Since 1979, Afghanistan lost over a million population and has world's largest displaced population. Modern history of Afghanistan is one of systemic violence. The ordinary Afghans, who saw some sign of hope with the departure of Soviet forces from Afghanistan in 1989, and then the fall of the Communist regime in 1992, were utterly frustrated to see their country going through another phase of destructive war. This was the worst period in the Afghan history after the Soviet withdrawal. The entire country was in the hold of numerous war loads with their respective system of administration. The image of the Mujahedeen, (heroes of Islam) became one of the reactionaries, fighting amongst themselves and unable to form a government. Though the Mujahedeen were successful in driving out the Soviets, they failed to consolidate their victory. ${ }^{1}$ They lacked the unity and organization required to do what has been the central role of government since time immemorial. For one whole week there was no government at all in Afghanistan. The making and breaking of alliances over night was common with Afghan leaders. There was insecurity and lawlessness. Many people were indulged in corruption, looting, drug trafficking and rape. The immorality was on the increase. The women honor was being looted in the broad day light. It was difficult to understand who was fighting whom, and why. There was a Hobbesian war of all against all without a Leviathan (Leviathan could be a monarch or some other authority that takes central control of a state). The country was suffering from leadership vacuum. Economy of the country was already ruined by the previous war, got worsen now; while America turned its back towards Afghanistan, once its purpose was fulfilled in Afghanistan. ${ }^{2}$

\section{Emergence of the Taliban}

In reaction to the lawlessness after the Soviet withdrawal from Afghanistan, Afghan Islamic students' mostly rural Pashtun origin formed the Taliban movement between 1993-1994. This movement was led by Mullah Omar. He founded Tehrik-e-Islam-e-Taliban Afghanistan with the help of some Taliban to bring peace and introduce Islamic values in Afghanistan. ${ }^{3}$ The Taliban appeared to emerge out of nowhere when they first came to the world's notice in October 1994. They were welcomed by Afghan population tired of war and disgusted by Kabul's inept, corrupt Mujahedeen government led by Burhanuddin Rabbani. The central tenet of the Taliban creed, when they took power in Kandahar in October 1994, was to free Afghanistan from the criminal gangs and armed militia groups who were terrifying citizens since April 1992, and to establish an

\footnotetext{
${ }^{1}$ Kaplan D. Robert, Soldiers of God with Islamic warriors in Afghanistan and Pakistan, (New York: Vintage departures edition, 1990), p. xvi.

Jalalzai Musa Khan, Foreign Policy of Afghanistan, (Lahore: Sang-Meel Publications, 2003), p.290.

${ }^{3}$ Ibid, pp. 290-291.
} 
Islamic state based on Sharia Law. ${ }^{4}$ Without any fighting, they captured over $90 \%$ of the Afghan land. They did not engage in looting, rape or mindless destruction when taking new areas. That was the reason perhaps that Ismail khan handed over Herat to the Taliban easily, without any fight. After capturing the main cities of Afghanistan, the Taliban conducted house-to house searches to disarm the population. In this way, Taliban has been successful in restoring peace, law and order, de-weaponization, eliminated war lordism, giving people a sense of security and honor. They were welcomed as the new rulers of Afghanistan who brought peace and stability in the areas under their control than the Afghan people had seen for two decades..$^{5}$ United States too favored the Taliban as a force of stability in Afghanistan, and supported them through its allies; Pakistan and Saudi Arabia. ${ }^{6}$

The Taliban were graduates and students of religious seminaries, played a significant part in the struggle against Soviet occupation but did not have any organization and played no role in the new power structure under the Mujahedeen war loads. They had a little experience in running government administration, nor did they see this as a priority when they took power. They primarily focused on the eradication of corruption and on the achievement of law and order. The maintenance and strengthening of administrative structure have been very much secondary concern. The Taliban said that they were disinterested in governance, they have entered scene only to bring peace and order. ${ }^{7}$ Their declared objective included establishment of "Pure Islamic state", implementation of Sharia Laws. The simple and idealistic group with only religious education, lacked sophistication as well as understanding of International law and world politics. They implemented strictest interpretation of Sharia laws ever witnessed in the world. The Taliban put a ban on the employment of women, and imposed strict dress codes on both women and men. ${ }^{8}$ The state Department spokesman Glyn Davis said, "The U.S. found nothing objectionable in the steps taken by the Taliban to impose Islamic laws." The first expression of a change in U.S. policy was articulated when secretary of state Madeline Albright visited Islamabad in November 1997 and called Taliban 'despicable' for their gender policies. ${ }^{9}$ The human rights and women issues had thrust itself on the American feminists against the Taliban. Madeleine Albright said, "It is difficult to modernize a nation if half or more of the population is left behind". She said, "If the society is to move forward, women and girls must have access to schools and health care. They should be able to participate in the economy." 10 According to UN survey conducted in May 1996, Kabul had 158 public schools, accommodating 148,223 boys and 103,256 girls taught by 11,208 teachers of whom 7,793 were women. Because of high percentage of female teachers, the restrictions effectively deprived boys as well. ${ }^{11}$ Prior to Taliban control, " $70 \%$ of school teachers (including $60 \%$ of those at Kabul University), $50 \%$ of civilian government workers, and $40 \%$ of doctors in Kabul were Women. ${ }^{12}$ People were liberated from the threat of insecurity and lawlessness and roped by the strict interpretation of Sharia laws. On the one hand people of Afghanistan were signing the songs of praise of Taliban for peace and security they brought to the war torn country, but on the other hand, as many as 50,000 refugees who have fled to Pakistan have done so because they were suddenly deprived of female earnings. ${ }^{13}$ The Taliban have stated that halt is temporary. They will consider allowing women to work once they made arrangements allowing women and men to work separately and travel separately. A meeting held between UN agencies and the Taliban acting foreign minister, Haji Malwai Mohammad Ghaus Akhund, on Sep. 1996, on the issue of restrictions on the employment of women. The minister responded that the priority of the Taliban was to bring peace and security to the whole country, and to establish a strong, central Islamic government. He indicated that when the Taliban regime was accorded International recognition responses to other issues would be clarified. He observed that only 2 percent of women nationwide worked in offices and asked why they should focus on this 2 percent. ${ }^{14}$ Any dialogue has to be based on a respect for values that participant in the dialogue adhere to. The difficulty arises when one or both parties to a dialogue are taking what is regarded as an extreme or rigid position. The world community criticized the Taliban rule as discriminatory towards women rights and minorities by which they failed to get recognition in the world body.

It may be easy and obvious for victims to blame Taliban officials for their egregious crimes, and in fact they are blame worthy, but the social and economic context that contours the Taliban in its own way facilitated

\footnotetext{
${ }^{4}$ Ibid, p.62.

${ }^{5}$ Marsden Peter, The Taliban War, Religion, and the New Order in Afghanistan,(Karachi: Oxford University press, 1998$)$, p. 48.

${ }^{6}$ Shamas-Din and Sarkar Bhaswatin, Afghanistan and Central Asia in the New Great Game,(New Delhi: Lancer Books, 2003 ), p.90.

${ }^{7}$ Ibid, p. 45

${ }^{8}$ Marsden Peter, Op cit, p.88.

${ }^{9}$ Shamas-Din and Sarkar Bhaswatin, Op cit, pp. 90-91.

${ }^{10}$ Mackenzie Richard, The United States and the Taliban in Maley William(ed.), Afghanistan and the Taliban, the Rebirth of Fundamentalism, (India: Pengium books, 2001), p.90.

${ }^{11}$ Keating Michael, Dilemmas of humanitarian assistance in Afghanistan, in Maley William (ed.), Op cit, p.154

${ }^{12}$ See Wiley Shannon A, Fighting Back Against The Taliban, The case for restoring Afghan Men and Women's Right to Self- Determination available at, http://Scholarship.law.wm.edu/wmjowl/vol7/iss2/8, [last visited 10 Feb. 2013] , Footnote no. 54.

${ }^{13}$ Marsden Peter, Op cit, p.89.

${ }^{14}$ Ibid, p.110.
} 
the commission of such systemic human rights abuses. Taliban were looking for recognition and financial assistance to revive an economy that was in a state of total turmoil. The Taliban have repeatedly demonstrated powerful commitment to the welfare of the population. But the Taliban and international community's notion of what comprises social wellbeing are hardly comparable. The western society is relatively individualistic, each individual, female or male, will normally seek fulfillment on the basis of personal life choice. Such an approach to life has never existed in large majority in Afghanistan. Western approach to life has remained favorite only amongst a small minority, and many of these have left the country for the West. However, Western observers spontaneously identified with this minority. ${ }^{15}$ The USA and Europe primarily, on the basis of their own value system, decide that the policies and actions of the Taliban are unacceptable and that International recognition is not appropriate. For this reason Taliban remain highly isolated internationally. The Taliban considered world body inherently biased and had no incentive to cooperate with it.

It is less easy to understand why the Taliban regime have been the subject of doubt when so many other regimes, with questionable human rights practices, have been accorded recognition. It is notable the communist regime had immediately secured recognition in 1978 even though majority of the Afghan people were clearly opposed to it. Similarly, Rabbani was given recognition even though he was bitterly opposed by the Hekmatyar in a bloody civil war. Rabbani continued to hold seat at the United Nations even when Rabbani regime did not exist. For over four years, Afghanistan was under effective control of the Taliban and according to International practice they had every right to represent Afghanistan in the world body. ${ }^{16}$ In the initial years of their rule in late 1997, the Taliban reportedly banned opium poppy cultivation. The increased need for immediate cash compelled the Taliban to lift its ban on poppy growing and started instructing the farmers to cultivate the opium for export. In remarks delivered 2 October, 2001, British Prime Minister, Tony Blair, referred to the Taliban as, "a regime founded on fear and funded on the drug trade". To break the back bone of the Taliban regime; economic sanctions were imposed on Afghanistan under UN Resolution 1333 of December 20, 2000, which harmed Afghan civilians more than the officials of the Taliban. ${ }^{17}$

What need to be underlined is that the Taliban were not the first Afghan authorities to abuse human rights, and it is often remarked that a little concern was expressed by western politicians in the past. The Northern Alliance ${ }^{18}$ commanders were responsible for murder, rape, loot, and displacement are not condemned with the same intensity as the Taliban. ${ }^{19}$ Under the Taliban rule, law and order improved in Afghanistan. The Taliban forces have not manifested a tendency to rape or loot in the wake of battle or to abuse women sexually. They run government smoothly and efficiently. To promote multi-ethnic and democratic image they have given representation to non-Pushtuns in the administration. ${ }^{20}$ The ideological formation of Taliban has historical roots in the emergence of the mushrooming growth of thousands of madrassas across Pakistan. The Taliban alternative for the education system of Afghanistan followed the same direction as in Pakistan by establishing as many madrassas as possible. These madrassas can attract large funds from Saudi and other Gulf countries. It was the primary target of their agenda. ${ }^{21}$ Musa Khan jalalzai, an Afghan journalist, in his book "The Foreign policy of Afghanistan" writes that, "The Taliban were the products of the madrassas based on narrow rigid and orthodox interpretation of Islam. From their emergence in an ultra-orthodox mode up to the present day, they seemed to have moderated significantly. The World Community provided a blind eye to the thirteen girls' schools that were opened in Kabul by the Taliban. ${ }^{22}$ The UN secretary General Kofi Anan accused the Taliban of "massive human rights violation". 23

Since the end of the Cold War, no other political movement in the Islamic world attracted as much attention as the Taliban in Afghanistan. The isolation of the Taliban and their grievances against the International organization over non recognition and harsh international criticism of the Taliban hardened the Mullah Omer's view that only a military approach could bring success to the Taliban. In 1996, Osama Bin Laden moved to Afghanistan and the Taliban welcomed him because he shares their deep distrust of the U.S.,

\footnotetext{
${ }^{15}$ Ibid, pp.99-100.

${ }^{16}$ Amin M. Shahid, Pakistan's Foreign Policy; A Reappraisal, (Karachi: Oxford University Press, 2010), pp.113-114.

${ }^{17}$ Perl Raphael F, The Taliban and Drug Trade, order code RS21041, Oct. 5 2001, available at, CRS, the library of Congress, [last visited $18^{\text {th }}$ July, 2012].

${ }^{18}$ The supreme council for the defense of Afghanistan commonly known as Northern Alliance was a military Front. Ahmad Shah Massoud and Abdul Rashid Dostum, created the United Front (Northern Alliance) against the Taliban in late 1996.It included beside the dominantly Tajik forces of Massoud and the Uzbek forces of Dostum, Hazara troops led by Haji Mohammad Mohaqiq and the Pushtun forces under the leadership of commander such as Abdul Haq and Haji Abdul Qadir. For further details see,

Khan Riaz Mohammad, Afghanistan and Pakistan: Conflict, Extremism, and Resistance to Modernity, (New Delhi: Oxford University Press,2011),PP.63-65.

${ }^{19}$ Keating Michael, Op cit, p.138.

${ }^{20}$ Jalalzai Musa Khan, Op cit, p.294

${ }^{21}$ Nojumi Neamatollah, The Rise of the Taliban in Afghanistan; Mass Mobilization, Civil War, and the Future of the Region, (New York: Palgrave, 2002), p.121.

${ }^{22}$ Jalalzai Musa Khan, Op cit, pp.295-296.

${ }^{23}$ Khan Riaz Mohammad, Op cit, p.73.
} 
and moreover he provided the financial help to the cash-starved Taliban. Osama Bin Laden's famous network, 'Al-Qaeda' took the advantage of Taliban hospitability and the military training they could receive inside Afghanistan. Taliban became dependent on the foreign militant element that provided them with funds. Taliban destroyed the eighteen hundred years old colossal Buddha carved in the sand stone hills facing Bamiyan city. Reacting to the world wide criticism over this action, the Taliban foreign minister Mullah Wakal Ahmad Mutawakil said that 'the world could hear the Buddha statue's exploding but failed to listen the cries of our hungry children. ${ }^{24}$ Afghanistan became an ungoverned land conducive for jihadists, militancy and extremists. By providing the refuge to the leader of Al-Qaeda an alien body, Afghanistan turned into a new $21^{\text {st }}$ century storm centre.

\section{9/11 and the U.S. Intervention in Afghanistan}

Afghanistan became the target of a new U.S. hot war in Asia, after the 9/11 attacks on the U.S., by suspected Osama Bin Laden. Terrorism appeared to displace communism as the world's defining cleavage. The U.S. turned up pressure on the Taliban through the United Nations Security Council 'Turn Over' Osama Bin Laden or to stop providing safe haven to Osama. When Taliban refused to extradicate bin laden, Bush administration decided the military overthrow of the Taliban. Never in the past, had a country as powerful as the U.S., had waged a war against a single individual and not a state. US waged "war on Terrorism" against AlQaeda and its leader Osama Bin Laden. The U.S. disregarded all existing international laws and norms, when it got engaged in a 'global war against terrorism'. It gave itself the right to attack any deemed 'enemy' which could be countries and regimes as well as groups or individuals since no distinction was to be made between terrorists and countries harboring them. On 7 October 2001, the U.S. launched aerial and missile strikes against the Taliban and the Al-Qaeda networks in Afghanistan. U.S. attacked the Taliban and demolished the Taliban regime. ${ }^{25}$

No knowledgeable authority seriously questioned the UN estimate that 7.5 million Afghans need food over the winter-2.5 million more than on September 11, a 50 percent increase as a result of threat of bombing. ${ }^{26}$ The U.S. bombing of Kandahar was so severe that roughly 80 percent of Afghan population of the city fled and most buildings simply collapsed, ${ }^{27}$ then the actuality, with a toll that will never be investigated if history is any guide. The Women's International League for Peace and Freedom invoked moral opposition to war, stated, "we don't want bombs dropped on a country where 7 million people already face starvation, $60 \%$ of them women and children, ....... ${ }^{, 28}$ U.S. claimed of waging a just war is itself deemed false and unacceptable. Had U.S. used just means in waging the so called just war i.e. taking sufficient care not to cause sufferings to 'innocents.' Innocent civilians were killed who had no connection what so ever to the event of $9 / 11$ event. The world body failed to make distinction between Al-Qaeda an alien body and the Taliban who were an integral body of Afghan society and had ruled Afghanistan with certain gross root legitimacy and support. The Taliban were designated as terrorists along with Al-Qaeda by United Nations. ${ }^{29}$ Condoleeza Rice ${ }^{30}$ insists, that "U.S. will fight poverty, disease, and oppression because it is the right thing to do and the smart thing to do." ${ }^{31}$ But on the other hand, Niaz Naik, the dean of Pakistan's diplomatic corps, said on the BBC that, 'he had been told by the Americans during the summer of 2001, that invasion would begin in October. The event of 11 September came between the making of the design and its execution'. It would be naïve to think that human rights violation was of any concern for the U.S. ${ }^{32}$ The war on terror was actually in an important sense a fight for the control over the immense and largely untapped economic resources of the Asian republic of the former USSR. When the Taliban refused to cooperate fully with the U.S. in its designs on Central Asian oil, the U.S. decided to invade.

The 2001 ouster of the Taliban government paved the way for the success of a long-stalled UN effort to form a broad based Afghan government. The United Nations invited major Afghan fractions, most prominently

\footnotetext{
${ }^{24}$ Ibid, pp.80-81.

${ }^{25}$ Haider Salman(ed.), The Afghan War and its Geopolitical Implications for India, (New Delhi: Manohar Publishers \& Distributors, 2004) ,p.118

${ }^{26}$ Chomsky Noam, Who are the Global Terrorists? in Dunne Tim and Ken Booth(eds.), Worlds in Collisions, Terror and the Future of Global Order, (New York: Palgrave Macmillan, 2002), p. 134.

${ }^{27}$ Ahmad Ajaz, Iraq, Afghanistan the imperialism of our times, (New Delhi: Left world, 2004), p.221.

${ }^{28}$ Maney Gregory M, Woehrle Lynne M, and Coy Patrick G, Harnessing and challenging Hegemony: The US peace Movement After 9/11, available at www.kent.edu/cacm/faculty/.../harnessing-and-challenging-hegemony.pdf, [last visited Nonvember,2013], P.374.

${ }^{29}$ United Nations Security Council resolutions 1267 and 1333, which imposed sanctions against the Taliban, lumped the Taliban leaders together with Al-Qaeda. For further details

Visit [en.wikipedia.org/wiki/UnitedNationsecurity_council_Resolution_1267\#impositions_of_sanction]

Visit also, [www.internation.gc./sanctions/terrorists-terrorises.aspx].

${ }^{30}$ Condoleeza Rice is an American political scientist, diplomat, and war criminal. From 2001-2005, she was named as National Security Advisor.

${ }^{31}$ Laffler Melvyn p, 9/11 and the Past and Future of American Foreign Policy, International Affairs, Vol., 79, No.,5,(October 2003),

available at http://www.jstor.org/stable/3568953, [last visited 13 September, 2010], p. 1056.

${ }^{32}$ Ahmad Ajaz, op cit, p.261.
} 
the Northern Alliance, but not the Taliban to an international conference in Bonn, Germany. On December 5, 2001 the factions signed the "Bonn Agreement" Interim administration. The Northern Alliance, has now returned to power as a dominant faction in the karzai government, while Pushtuns which is the dominant tribe, constitutes approximately $45 \%$ of the total population of the country, got underrepresentation in the new government. ${ }^{34}$

Nevertheless, World Community got engaged in various-action oriented programs in Afghanistan with the objective of its reconstruction depth and ushering in peace and stability into this war torn region. Afghanistan has witnessed some progress in terms of human rights, political and economic reforms and infrastructure buildings. Achievements have been recorded in public health and education. All observers agree that Afghan women are freer than they were under the Taliban. After the U.S. intervention in Afghanistan, the outlook for Afghanistan is brighter now, than it has been for a long time. 2.3 million refugees have come back Afghanistan, and 6,00000 Internally Displaced Persons have returned to their homes. The flood of returning refugees, exceeding aid agencies, expectations bears this out remarkably. It may thus well be the first real victory in the US led war against terrorism. ${ }^{35}$ The country could have been on the better path of political stabilization and economy recovery, had Afghanistan received focused world attention. To banish terror from International politics and to make world safe for democracy, diversity, and social justice will demand a sustained material and moral commitment. ${ }^{36}$ In 2003, U.S. intervened in Iraq, leaving Afghanistan in the state of instability.

Local war loads were empowered whose existence is predicated on foreign backing rather than popular support, contrasts sharply with the vision of a democratic, representative government that drives the Bonn Accord. ${ }^{37}$ The U.S. main aim was to eliminate the Al-Qaeda and the Taliban sanctuaries in Afghanistan. Searching and elimination of the Al-Qaeda and the Taliban means strengthening the war loads in Afghanistan as U.S. does not have enough troops for longer ground operations which were carried by the latter. These war loads were militarily stronger than Karzai himself. ${ }^{38}$ War loads returned to their old ways, more interested in rape and child abuse and heroin sales than developmental tasks. According to UN 2007 World Drug Report, opium production in Afghanistan has increased by nearly 100 times since 2001 . The country accounts for $93 \%$ of the illicit opium crop. ${ }^{39}$ The highly centralized Afghan government offers little protection from corruption. In fact, there are indications that present government is more corrupt than the Taliban. The largest Drug Barons continue to hold positions in government and parliament. Some are closely connected to president Karzai himself. The State Department report on human rights practices for 2009, (released Mar. 11, 2010), said that Afghan human rights record remained "poor", till virtually. The Soviet invasion and the civil war to follow was the outpouring of at least 3 million Afghan refugees into Pakistan between 1979-89. After the US -led toppling of the Taliban in 2001, the figure reached to five million, out of which $85 \%$ refugees were ethnic Pushtuns. March 2009, 1.7 million registered Afghans have repatriated. Pakistan consistently upholds itself as one of the largest refuge- hosting countries in the world. Due to widespread violence and insecurity, Afghanistan has experienced extensive internal displacements. Presently, there are about 240,000 'conflict-induced' Internally Displaced Persons (IDP) in Afghanistan. In October 2010, it was reported that over 100,000 Afghans had been forced out of their homes in Afghanistan in the previous year. ${ }^{40}$ Afghanistan continues to play the central stage for all the wrong reasons like terrorism, poppy production, drug trafficking and insurgency under U.S. occupation with full participation of its clients in the Northern Alliance.

\footnotetext{
${ }^{33}$ International community as well as the four major Afghan groups, the Northern Alliance; supporters of former King Mohammad Za hir Shah (Known as the Rome Group because many had relocated there); former leaders of Pakistan (known as the Peshawar Group); and a group of opposite figures with links to Iran (Cyprus Group) gathered in Bonn(Germany) on Nov.26, to discuss the political future of Afghanistan. The four groups concluded an agreement on an interim setup, on Dec. 5 2001. Hamid Karzai was nominated as Chairman of the twenty-nine member Interim Administration. For details see

Fields Mark and Ahmad Ramsha, A Review of the Bonn Conference and Application to the Road Ahead in Afghanistan, ( Washington: National Defense University Press, Nov. 2011), see also Jalalzai Musa Khan, Foreign Policy of Afghanistan, (Lahore: Sang-Meel Publications ,2003), pp.227-228.

${ }_{35}^{34}$ Shamas -Din and Sarkar Bhaswatin, Op cit, p.10.

${ }^{35}$ Sirrs Julie, Has the war Been won?, in Hussain Rifaat Dixit J.N, and others(eds.), Anatomy of a Conflict Afghanistan and 9/1 1, (New

Delhi: Lotus Collection,2002).

${ }^{36}$ Mehta Jagat S, The March of Folly in Afghanistan 1978-2001, (New Delhi: Manohar Publications, 2002), pp. 220-221.

${ }^{37}$ Misdaq Nabi, Afghanistan, Political frailty and External Interference, ( London: Taylor and Francis, 2006 ), p.252.

${ }^{38}$ Ahmad Ajiz, Op cit, p.217.

${ }^{39}$ Ibid, p. 158

${ }^{40}$ See Siddiqi Shibil, Afghanistan-Pakistan Relations: History and Geopolitics in a Regional and International context, available at www.gordonfn.org/resfiles/siddidiqi Pak\%20final2.pdf, [last visited 31st July 2012], pp.14-15.
} 


\section{International Assistance in Afghanistan}

There is a lot of variations in data available on the international assistance in Afghanistan is concerned. One interpretation is that Afghanistan has received too little assistance to carry state building process in Afghanistan. Afghanistan required a big money to rebuild its devastated economy. Despite the large volume of aid, most international spending "on" Afghanistan is not spent "in" Afghanistan. The promised aid is not being delivered in the measure committed by international community. There is a deep truth hidden in the so called 'humanitarian aid'. What the U.S. is doing is buying clients among the elites. They are likely to throw money at the corpses and call it 'humanitarian aid ${ }^{41}$ Of the $\$ 40-\$ 50$ billion in aid allocated to Afghanistan at various international donor conferences, only \$13billion has been allocated to the government of Afghanistan. $75 \%$ of the aid money goes in providing the requisite infrastructure to the international workers to function and really acts as phantom aid rather than real aid. ${ }^{42}$

The $2^{\text {nd }}$ conflicting interpretation is that Afghanistan has received too much assistance. This argument holds that the large quantity of assistance is harmful to state-building. The huge amount of assistance in Afghanistan has been delivered outside the control of the Afghan government which led to the problems like corruption, inefficiency in administration, and above all Afghanistan became dependent on foreign assistance, while compromising with its sovereignty. John F. Sopko, Special Inspector General for Afghanistan Reconstruction (SAGAR), in his latest quarterly report to US Congress, writes that the US appropriations for the reconstruction of Afghanistan exceed the funds committed to the Marshall plan. Afghan-reconstruction appropriations amount to more than $\$ 109$ billion, versus an adjusted total of 103.4 billion for the Marshall Plan. ${ }^{43}$ It is more than likely that political stability and reconstructed economic infrastructure are not effectively and expeditiously created and justly distributed. ${ }^{44}$ The U.S. spend billions of dollars on the war on terror, while a little fraction of it is spend on eliminating poverty, providing education, and healthcare to the people. International community failed to recognize the well coordinated and coherent approach to tackling the problems in Afghanistan. 70 percent of Afghan population still lives below the poverty line. Young generation which comprised of over 86 percent of Afghanistan, are at the cross -roads. They are without jobs. ${ }^{45}$ Only a small number of Afghans who work for foreign companies earn adequate wages, where as those who are employed in the public sector earn an average of less than $\$ 50$ a month. ${ }^{46}$ There is no manufacturing in Afghanistan, which deprived the country for a major engine of growth. The Afghan leadership is not addressing the immediate needs of the citizens, thus creating a disconnect and a void between the population and the government. People of Afghanistan have lost their trust in the government. ${ }^{47}$ In the last 10 years, efforts have no doubt been made for the reconstruction of the country, but public interest has still been over-shadowed by the military, political, and sometimes, personal agendas. Patience is running out for many, and the political and AlQaeda offer financial opportunities that many of the poor cannot find elsewhere. ${ }^{48}$ Failure on the part of the karzai government to fulfill the high expectations of the people, the war lords return to their old marauding ways, the America's botched bombing raids, and slow reconstruction are all creating conditions favorable for the return of the Taliban. Most Human rights organizations have written about abuses by U.S. troops in Afghanistan. The New York based human Rights Watch report said that the U.S. forces operating in Afghanistan have arbitrarily detained civilians and their administered system of arrest and detention in Afghanistan 'is outside the rule of law. ${ }^{49}$ Taliban started regrouping and attacking the American forces and governmental offices. Just as much as the older generation of Afghan Taliban was a consequence of the Soviet invasion, the new Taliban is a result of American intervention. ${ }^{50}$ A great victory for Washington by the fall of the Taliban-is now seeing return of the old status quo. U.S. has been unable to establish viable government structure to stamp out corruption and contain militant insurgency in Afghanistan. According to just war tradition, has an end in view - a goal of expected victory and conclusion- at which point peace can be established in the defeated country. U.S. has met none of these goals neither in Afghanistan. The US war turns

\footnotetext{
${ }^{41}$ Ibid, p.63.

${ }^{42}$ Haider Salman, Op cit, pp.100-101

${ }^{43}$ Marsahall Plan is the US aid program that delivered billions of dollars between 1948 and 1952 to help 16 European countries recover in the after math of World War-11. For Further Details Visit, www.sigar.mil/pdf/quartely reports/2014 07-30qr.pdf. Last visited, ${ }^{\text {th }}$ August, 2014.

${ }^{44}$ Haider Salman, Op cit, pp.100-101.

${ }^{45}$ Saifullah Ahmadzai, Non-traditional Security Issues in Afghanistan, in Nayak Nihar(ed.), Cooperative security framework for south Asia, (New Delhi: Pentagon Press, 2013), pp.188-189.

${ }^{46}$ Ghufran Nasreen, "Afghanistan in 2007, A bleeding wound”, Asian survey, vol. 48, No.1, Jan/Feb. 2008, available at, http//:www, Jstor.org/stable/10.1525/as.2008.48.1.154, [last visited March 2012], p.159.

${ }^{47}$ Sultanzoy Mohammad Daoud, Prospects of cooperative security frame work for Afghanistan, in Nayak Nihar R, (ed.) Cooperative security Framework for South Asia,(India: Pentagon Press, 2012), p.83.

${ }^{48}$ Ghufran Nasreeen, Op cit, p.160.

49 Misdaq Nabi, Op cit, p.255.

${ }^{50}$ For further details on the resurgence and regrouping of Taliban see karlekar Hiranmay, Endgame in Afghanistan For Whom the Dice Rolls, ( India: sage Publications,2012).
} 
out to be endless warfare with no peace and no conclusion. ${ }^{51}$ American defense expenditures continue to rise, preventive wars are in the works, and fears of global threats to freedom and democracy are as strong as ever. ${ }^{52}$ America cannot win but it shall not suffer substantially either. The Afghans shall not be subjugated but they shall suffer. That is the asymmetry of power in our times. ${ }^{53}$ The U.S. prepares for the 'end game' i.e. a face saving strategy for the exit from an unwinnable war. To accomplish that they require a graceful exit strategy and a stable Afghanistan is nearly impossible without talking to the Taliban. What have changed are America's objectives from defeating the Taliban to making peace with them. The US has resorted to the 'mixed strategy' of war and diplomacy, peace initiatives and 'drone attacks' have gone side by side. This is also the strategy of pushtun militants who are continuing with their violent offensive in order to maximize their bargaining leverage in the peace talks. ${ }^{54}$ The former ISI chief Hamid Gul publicly proclaimed that, 'America is history, Karzai is history, and the Taliban are the future'. ${ }^{55}$ Political pendulum in Afghanistan continued to swing widely. One thing that remained common to all regimes in Afghanistan is that no regime worked for the welfare of Afghanistan as a whole. Taliban showed concern for Pushtun majority at the cost of other ethnic groups, U.S. backed Karzai government worked for some ethnic groups and discriminated the Pushtun group. Not to talk of civil war period, when all the sects of Afghan society were bleeding badly. Peace continues to elude from Afghanistan.

\section{Conclusion}

Afghanistan faced a series of wars and conflicts with changing actors alternatively in power or opposition from the last 35 years. The latest is the ongoing conflict between government and international forces and Taliban. Over three decades of constant warfare in which the country's entire infrastructure was demolished and its population was able to do little more than survival. Decades of warfare in Afghanistan left about 2 million dead, 700,000 widows and orphans and about one million Afghan children who were born and raised in refugee camps outside in Afghanistan. ${ }^{56}$ The common Afghan people have never seen peace and security under any regime till this date. The worst situation developed when Afghanistan became the battle ground for super power rivalry at the last front of the Cold war. USSR withdrew leaving Afghanistan in a state of total turmoil. During the civil war period, the entire country was in the hold of numerous war loads with the respective system of administration. This was the worst period in Afghan history, after the Soviets withdrew from Afghanistan. Then came the Taliban on the stage but could do little for the welfare of the general Afghan people. They provided Afghans greatly enhanced security, but they themselves terrified citizens especially women and minorities, with tyrannical rules. Hobbesian prediction fails in the case of Afghanistan, as Karzai a new Leviathan could not give security to the Afghan citizens. In recent years, life has become nastier and more brutish for the people of Afghanistan. U.S. and International community failed to recognize the well coordinated and coherent approach to tackle the problems in Afghanistan. Bringing Afghanistan on the track of development, peace and prosperity is still a challenge to be dealt in the future.

\section{Acknowledge}

I am indebted to my learned supervisor, S.R.T.P. Sugunakara Raju, Assistant professor, in the department of Political Science, Jamia Millia Islamia, New Delhi, for his guidance and assistance in the completion of this work.

\footnotetext{
${ }^{51}$ Salahuddin S. V, Militancy in Pakistan and Afghanistan(A brief History of causes and Effects), (New Delhi: Pentagon Press, 2012 ), p.83.

${ }^{52}$ Skillen James W, With or Against the World? America's Role Among The Nations,( USA: Roman and Littlefield Publishers, 2005 ),p.91

${ }^{53}$ The Hindu Newspaper, (2 ${ }^{\text {nd }}$ Jan., 2013), p.11.

${ }^{54}$ Baral J.K, The Afghan Game: Interests and Moves, Strategic Analysis, 2013, Vol,37, No. 6, pp. 700-715 http://dx.doi.org/10.1080/09700161.2013.847038, [accessed on11 March,2014], p.709

${ }^{55}$ Scott David (ed.), Hand book of India's International Relations, (London and New York: Routledge Taylor \& Francis Group), 2011 , p.114. ${ }^{56}$ Awasthy H.K, Quest for Survival, (India: Sumit Enterprises, 2012), p.261.
} 